\title{
Relationship among mammographic findings with histopathologic type of breast cancer and human epidermal growth factor receptor 2 (HER2) in young women
}

\author{
Donya Farrokh ${ }^{1}$, Samineh Boloursaz ${ }^{2}$, Fatemeh Homai ${ }^{3}$
}

${ }^{1}$ MD, Radiologist, Associate Professor, Radiology Department of Imam Reza Hospital, Mashhad, Iran

${ }^{2}$ MD, Radiology Resident, Radiology Department of Imam Reza Hospital, Mashhad, Iran

${ }^{3} \mathrm{MD}$, Oncologist, Associate Professor, Oncology Department of Ghaem Hospital, Mashhad, Iran

Type of article: Original

\begin{abstract}
Introduction: Radiological measures to diagnose breast cancer, including mammographic and ultrasound assessments in young women, are associated with restrictions affecting the use of this tool. No adequate information is available on mammography view in young people with breast cancer and its relationship with pathologic type and epidermal growth factor receptor 2 (HER2) as a prognostic marker, especially in the Iranian race. This study was conducted to examine the relationship between mammographic findings of young women with breast cancer with diagnosed histopathologic type and HER2 marker status.

Methods: This retrospective cross-sectional study was carried out on women with breast cancer referred to Omid Hospital in Mashhad, Iran. Inclusion criteria were age less than 45 years and definitive diagnosis of breast cancer documented in the patient record. Information on mammographic findings such as mass, asymmetry, microcalcification, tissue distortion, nipple retraction, and skin thickening was collected from patient medical records. In addition, the type of pathology diagnosed based on biopsy samples and HER2 examination results were collected. The chi-square test and SPSS software were used to analyze the relationship among qualitative variables.

Results: This study was performed on 153 patients with a mean age of $39.3 \pm 2.5$ years (minimum 20 years and maximum 45 years). The mammographic finding was reported normal in 41 patients $(26.7 \%)$. The evidence of malignant mass was observed in 48 patients (31.3\%). The microcalcification was found in 31 patients (20.3\%). The retraction or thickening of breast tissue was seen in 39 patients $(25.5 \%)$. The distortion of breast stroma was found in 41 patients $(26.8 \%)$. The HER2 marker in 76 patients $(49.7 \%)$ was positive in study subjects. There was no statistically significant association between mammographic findings and pathologic type. Among the mammographic findings, only the presence of microcalcification had significant association with HER2 results $(\mathrm{p}=0.008)$.

Conclusion: It seems that a significant relationship could not be found between mammographic features in patients with breast cancer and type of pathology diagnosed. However, the presence of calcification in mammography is associated with positive HER2.

Keywords: Calcification, Breast, Neoplasm, Mammography, Pathology, ERBB2 protein, Ultrasonography
\end{abstract}

\section{Introduction}

Breast cancer is one of the most common cancers among women and, after lung cancer, is the second leading cause of cancer death in women aged 20-59 years (1-3). Between 5\% and 7\% of breast cancer cases occur in women under 40 years (3). Different epidemiology, presentation in more advanced stages, and more invasive phenotype can be observed in younger patients; hence, the breast cancer has received much attention for diagnosis and prognosis in young women $(1,3)$. The fact that Iranian women, when compared with those in developed countries, are suffering from breast cancer for at least a decade earlier, in addition to the high incidence of this disease in Iran, doubles the importance of this issue $(4,5)$. However, apart from cases diagnosed by screening of young people, which occurs in

\section{Corresponding author:}

Dr. Samineh Boloursaz, Radiology Department of Imam Reza Hospital, Mashhad, Iran. Tel: +98.9153228419, Email: S_boloursaz@Yahoo.com

Received: January 03, 2017, Accepted: February 22, 2017, Published: May 2017

iThenticate screening: February 02, 2017, English editing: March 10, 2017, Quality control: April 12, 2017

(C) 2017 The Authors. This is an open access article under the terms of the Creative Commons Attribution-NonCommercialNoDerivs License, which permits use and distribution in any medium, provided the original work is properly cited, the use is non-commercial and no modifications or adaptations are made. 
individuals with mutations in BRCA gene, the diagnosis of breast cancer in young women is still a challenging problem $(6,7)$. The efforts are on diagnosis and treatment more quickly in case of developing breast cancer by imaging-based screening in young people. However, the radiological measures to diagnose breast cancer, including mammographic and ultrasound assessments in young women, are associated with restrictions affecting the use of this tool $(8,9)$. Some of the reasons include lower percentage of incidence as focal lesions, out of standard screening guidelines, restrictions on mammographic assessment due to the high density of breast at the young age, higher incidence of benign lesions, different presentation for imaging of lesions and mimic benign view (10, 11). Apart from the mentioned limitations, there is little information on radiological diagnosis of breast cancer at early ages (12). On the other hand, there is no definite correlation among mammographic imaging findings with the breast cancer histologic type and prognostic markers (13). The HER2 oncogene as a prognostic marker encodes transmembrane glycoprotein with tyrosine kinase activity, and its overexpression can be seen and acts as a protooncogene $(14,15)$. Recently, physicians in addition to histopathologic tests in breast cancer samples examine the expression level of the HER2 marker, which has very high cost and sometimes the relevant centers are not available. Therefore, if the HER2 marker status is predictable in different views of mammography, the test performed on samples with low probability of overexpression of HER2 marker might be prevented in the future. This study was conducted to examine the relationship between mammographic findings of young women with breast cancer with diagnosed histopathologic type and HER2 marker status.

\section{Material and Methods}

\subsection{Study design}

This retrospective cross-sectional study was carried out on medical records of women with breast cancer referred to Omid Hospital in Mashhad, Iran, from March 2001 to March 2011.

\subsection{Sampling}

The sample size was determined by 155 patients using the formula of comparing proportions and taking into account the results of the study by Radenkovic et al. (16) and colleagues. In this research, alpha, beta, and significance level were set respectively at $5 \%, 80 \%$, and 0.05 . Sampling was conducted by using nonrandom convenience method.

\subsection{Inclusion and exclusion criteria}

Inclusion criteria were age less than 45 years and definitive diagnosis of breast cancer documented in the patient record. Exclusion criteria were familial or hereditary breast cancer and the absence of any of the information related to the physical examination, radiological, and sonographic findings.

\subsection{Data collection}

After extraction of the age, clinical examination data were recorded, including mass, discharge, and breast appearance. Then, information on mammographic findings such as mass, asymmetry, microcalcification, tissue distortion, nipple retraction, and skin thickening were collected from patient medical records. Moreover, concerning the patients undergoing core needle biopsy or excisional biopsy, the results were recorded as invasive ductal carcinoma, invasive lobular carcinoma, carcinoma in situ, medullary carcinoma, tubular carcinoma, colloid carcinoma, and phyllodes tumour. In the end, biological marker of HER2 result was recorded as HER2+ and HER2according to the patients' laboratory records.

\subsection{Ethical considerations}

Informed consent was completed for each patient after full explanation of study plan after a telephone call based on their available contract number of their medical records. Patients' secrets were kept completely confidential until the end of the study, and patient data were entered into statistical software as encoded. The ethics committee of Mashhad University of Medical Sciences approved this research project (code of ethics: ir.r.sm.rec.1394.260). In the event of any complication related to project, the researchers supported the patients completely.

\subsection{Statistical analysis}

Data were analyzed using SPSS version 16 (SPSS Inc., Chicago, Illinois USA). The quantitative variables were expressed by mean and standard deviation, and the qualitative variables were described with tables and graphs. The Chi-square test was used to analyze the relationship among qualitative variables.

\section{Results}

\subsection{Baseline characteristics}

This study was performed on 153 patients with the mean age of $39.3 \pm 2.5$ years (minimum 20 years and maximum 45 years). Two cases of familial breast cancer were excluded. Only 11 patients $(7.2 \%)$ showed no certain findings on 
http://www.ephysician.ir

physical examination. The most common clinical finding was mass touching $(\mathrm{n}=111,72.5 \%)$, and then skin changes $(\mathrm{n}=8,5.2 \%)$, pain $(\mathrm{n}=7,4.6 \%)$, and discharge $(\mathrm{n}=3,2.0 \%)$.

\subsection{Mammographic findings}

The mammographic finding was reported normal in 41 patients $(26.7 \%)$. The most common mammographic finding among the patients was mass $(n=89,58.9 \%)$. Based on the reports, the evidence of malignant mass was observed in 48 patients $(31.3 \%)$; 10 masses with irregular margins and margins 38 masses with speculated margins. The microcalcification evidence was found in 31 patients $(20.3 \%)$. The retraction or thickening of breast tissue was seen in 39 patients $(25.5 \%)$. The distortion of breast stroma was observed in 41 patients $(26.8 \%)$. The HER2 marker in 76 patients $(49.7 \%)$ was positive in study subjects.

\subsection{Pathologic findings}

The most common pathology diagnosed in the studied patients was invasive ductal carcinoma $(\mathrm{n}=121,79.1 \%)$, not otherwise specified (NOS) invasive carcinoma $(n=17,11.1 \%)$, invasive lobular carcinoma $(n=7,4.6 \%)$, carcinoma in situ $(n=3,2.0 \%)$, mucinous carcinoma $(n=3,2.0 \%)$ and medullary carcinoma $(n=2,1.3 \%)$, see Table 1 .

\subsection{HER2 marker}

The test result of HER2 tumor marker was positive in 76 patients $(49.7 \%)$ and negative in 77 study subjects $(50.3 \%)$.

\subsection{Relationship between mammographic and pathologic findings}

Based on the performed analyses, it was determined that there was no statistically significant association between mammographic findings and pathologic type (Table 1). Among the mammographic findings, only the presence of microcalcification had significant association with HER2 results, and no significant correlation was found among other findings (Table 2).

Table 1. Relationship between mammographic and histopathology findings of patients with breast cancer

\begin{tabular}{|c|c|c|c|c|c|c|c|c|}
\hline \multicolumn{2}{|c|}{ Mammographic findings } & \multirow{2}{*}{$\begin{array}{l}\text { Mucinous } \\
\text { carcinoma } \\
(n=3)\end{array}$} & \multirow{2}{*}{$\begin{array}{l}\text { NOS* invasive } \\
\text { carcinoma } \\
(n=17)\end{array}$} & \multirow{2}{*}{$\begin{array}{l}\text { Medullary } \\
\text { carcinoma } \\
(n=2) \\
0\end{array}$} & \multirow{2}{*}{$\begin{array}{l}\text { Carcinoma } \\
\text { in situ }(n=3)\end{array}$} & \multirow{2}{*}{$\begin{array}{l}\text { Invasive lobular } \\
\text { carcinoma }(n=7)\end{array}$} & \multirow{2}{*}{$\begin{array}{l}\text { Invasive ductal } \\
\text { carcinoma } \\
(n=121)\end{array}$} & \multirow{2}{*}{\begin{tabular}{|l|}
$p-$ \\
value \\
0.551
\end{tabular}} \\
\hline Type of margin & Malignant & & & & & & & \\
\hline microcalcification & Non-malignant & 2 & 17 & 1 & 2 & 3 & 80 & \\
\hline \multirow{2}{*}{$\begin{array}{l}\text { Retraction or thickening } \\
\text { of skin Distortion }\end{array}$} & Yes & 0 & 5 & 0 & 1 & 1 & 24 & \multirow[t]{2}{*}{0.756} \\
\hline & No & 3 & 12 & 2 & 2 & 6 & 97 & \\
\hline \multirow[t]{2}{*}{ Asymmetry } & Yes & 0 & 6 & 0 & 1 & 3 & 29 & \multirow[t]{2}{*}{0.560} \\
\hline & No & 3 & 11 & 2 & 2 & 4 & 92 & \\
\hline \multirow{2}{*}{$\begin{array}{l}\text { Type of margin } \\
\text { microcalcification }\end{array}$} & Yes & 0 & 4 & $\overline{0}$ & 0 & 3 & 34 & \multirow[t]{2}{*}{0.543} \\
\hline & No & 3 & 13 & 2 & 3 & 4 & 87 & \\
\hline \multirow{2}{*}{$\begin{array}{l}\text { Retraction or thickening } \\
\text { of skin Distortion }\end{array}$} & Yes & 0 & 3 & 1 & 1 & 3 & 23 & \multirow[t]{2}{*}{0.732} \\
\hline & No & 0 & 3 & 0 & 1 & 1 & 25 & \\
\hline \multirow[t]{2}{*}{ Asymmetry } & Lesional & 1 & 13 & 2 & 2 & 6 & 88 & \multirow[t]{2}{*}{0.565} \\
\hline & Normal & 2 & 4 & 0 & 1 & 1 & 33 & \\
\hline
\end{tabular}

* Not otherwise specified

Table 2. Relationship between mammographic findings and HER2 tumor marker of breast cancer patients

\begin{tabular}{|c|c|c|c|c|}
\hline \multicolumn{2}{|l|}{ Mammographic findings, $n$} & $\mathrm{HER}^{+}(n=76)$ & HER2- $^{-}(n=77)$ & $p$-value \\
\hline \multirow[t]{2}{*}{ Type of margin } & Malignant & 25 & 23 & \multirow[t]{2}{*}{0.842} \\
\hline & Non-malignant & 52 & 53 & \\
\hline \multirow[t]{2}{*}{ Microcalcification } & Yes & 22 & 9 & \multirow[t]{2}{*}{0.008} \\
\hline & No & 54 & 68 & \\
\hline \multirow[t]{2}{*}{ Retraction or thickening } & Yes & 20 & 19 & \multirow[t]{2}{*}{0.816} \\
\hline & No & 56 & 58 & \\
\hline \multirow[t]{2}{*}{ Distortion } & Yes & 23 & 18 & \multirow[t]{2}{*}{0.336} \\
\hline & No & 53 & 59 & \\
\hline \multirow[t]{2}{*}{ Asymmetry } & Yes & 18 & 13 & \multirow[t]{2}{*}{0.158} \\
\hline & No & 49 & 73 & \\
\hline \multirow[t]{2}{*}{ Overall results of mammography } & Lesional & 60 & 52 & \multirow[t]{2}{*}{0.111} \\
\hline & Normal & 16 & 25 & \\
\hline
\end{tabular}




\section{Discussion}

This study was conducted to evaluate the mammographic findings of young women (younger than 45 years) with breast cancer and their relationship with final pathologic type and expression of HER2 tumor marker. The results showed that mammography could identify symptoms match for breast cancer in about three-quarters of the patients. Among the mammographic findings, the calcification was only symptom associated with higher HER2 expression, and no relationship was found between other mammographic findings and histopathologic results or HER2 expression. In our study, invasive ductal carcinoma with the frequency of nearly $80 \%$ was diagnosed as the most common type of breast cancer; except for the frequency of not otherwise specified (NOS) invasive carcinoma (about $11 \%$ ), the incidence rate of other cancers was obtained less than $5 \%$. These findings are consistent with most studies in Iran (1-5, 7, 17 and 18). Also in the foreign studies, the prevalence rate of histologic types of invasive breast carcinomas for ductal and lobular carcinomas has been reported respectively about $80 \%$ and $10 \%$, and the remaining approximately $5 \%(19,20)$. However, what we will discuss further on is the key finding of this study, namely, the relationship between HER2+ and suspicious for malignancy micro-calcification seen on the mammogram. In the present study, the presence of HER-2 biomarker was positive in half of patients, which is nearly in line with other studies in Iran. It could possibly be due to almost identical scattering of pathologic type of breast cancer in previous studies. In fact, the tumors with HER-2/neu overexpression have worse prognosis, and since the majority of our patients had invasive malignant cancers with poor prognosis, the high frequency is justified. In a study of Moradi (21), similar to our study, almost $50 \%$ of patients had HER-2/neu+. In two other Iranian studies, the expression level of HER2+ was reported between $60 \%$ and about $70 \%(22,23)$, as well as $31.1 \%$ in another study, less than the results of recent studies (24). In European societies, the prevalence of HER-2/neu+ in breast cancer patients has been reported between $20 \%$ and $40 \%$ (25). However, apparently the differences could be certainly due to racial, genetic, and geographical factors $(14,26)$. In support of this, it can be referred to studies carried out among different races in America. It has been shown that there was significant difference in the incidence rate of prognostic genes expression and survival rate among different races (27).

In the present study, there was no relationship between status of HER-2/neu biomarker and none of the mammographic characteristics of the patients, except for microcalcification. Previously based on European and American studies, it was known that tiny or irregular linear and group calcification, also called malignant microcalcification, could sometimes be the only sign of breast cancer, even in the absence of a visible mass (28). The present study also showed that the presence of microcalcification is associated with HER-2+ among Iranian young women, which could be a sign for the weaker prognosis of the patients. In other studies in Iran, statistically significant association has been found among the status of HER-2/neu biomarker with a larger size of tumors, higher grade, lymph node involvement, distant metastases, lack of estrogen receptors, and higher recurrence rate. Our study is the first that focuses on these findings $(29,30)$. However, the relationship between the referred variables and HER2 + in Iranian society has not been confirmed decisively due to lack of studies, and the findings cannot be generalized. Nevertheless, it has been observed in other countries that HER2+ has higher frequency in patients with calcifications in mammograms (16). Therefore, the calcification found in mammograms in HER2-positive patients not only has diagnostic value, but also it can be effective in disease prognosis and assist in therapeutic options. However, it should be noted that the sample size of patients in the current study was small, which is one of the main limitations of this study. The important thing is that the biological mechanism of the relationship between calcification and HER2+ and the impact of the HER2 signaling pathways in observation of such findings in mammography should be examined in future studies. Another topic examined in this study was to evaluate the correlation between mammographic findings and the type of cancers diagnosed based on pathology, which no specific pattern was observed on the basis of our analysis. Perhaps the main reason for this is the small sample size in each pathologic subgroup. Although other studies have not also stated that whether or not any type of breast cancer will have particular views on mammograms. However, the material referred to in the literature is that there is the possibility of finding relationship between the type of mass and mass margin status and invasive ductal carcinoma (IDC) grades. However, this finding is not aligned in all studies.

\section{Limitations}

The use of different experimental techniques and the lack of comprehensive systems to standardize the diagnostic approaches have made different assessment of the status of biomarkers in some cases; there is always a percentage of error. The present study is also not an exception. In this study, various specialists and laboratory facilities have examined the tissue samples; thus, differences of opinion among the specialists can make differences in the final diagnosis. The HER2 marker also has been studied in different laboratories with various kits. On the other hand, the study was retrospective and based on hospital records. Many defects in closed records led to the exclusion of many 
cases from the study; further, many of the underlying variables were not verifiable. Therefore, it is suggested to be done prospective studies in future.

\section{Conclusions}

Based on the results of the present study, it seems that the significant relationship could not be found between mammographic features in patients with breast cancer and type of pathology diagnosed. However, the presence of calcification in mammography is associated with positive HER2. It is recommended that future researches examine the possible HER2 signaling pathways in developing the calcification.

\section{Acknowledgments:}

This study has been adopted from the results of research project (no. 940175) and PhD theses of Dr. Samin Boloursaz in radiology (code of thesis: T-4443). Research Deputy of Mashhad University of Medical Sciences, Iran, has funded the current study.

\section{Conflict of Interest:}

There is no conflict of interest to be declared.

\section{Authors' contributions:}

All authors contributed to this project and article equally. All authors read and approved the final manuscript.

\section{References:}

1) Parsa Y, Mirmalek SA, Kani FE, Aidun A, Salimi-Tabatabaee SA, Yadollah-Damavandi S, et al. A Review of the Clinical Implications of Breast Cancer Biology. Electronic Physician. 2016; 8(5): 2416. doi: 10.19082/2416, PMid: 27382453, PMCid: PMC4930263.

2) Mehrabi E, Hajian S, Simbar M, Hoshyari M, Zayeri F. Coping response following a diagnosis of breast cancer: A systematic review. Electronic physician. 2015; 7(8): 1575. doi: 10.19082/1575, PMid: 26816583, PMCid: PMC4725409.

3) Reyna C, Lee MC. Breast cancer in young women: special considerations in multidisciplinary care. Journal of multidisciplinary healthcare. 2014; 7: 419-29, PMid: 25300196, PMCid: PMC4189712.

4) Mousavi SM, Montazeri A, Mohagheghi MA, Jarrahi AM, Harirchi I, Najafi M, et al. Breast cancer in Iran: an epidemiological review. The breast journal. 2007; 13(4): 383-91. doi: 10.1111/j.15244741.2007.00446.x, PMid: 17593043.

5) Harirchi I, Ebrahimi M, Zamani N, Jarvandi S, Montazeri A. Breast cancer in Iran: a review of 903 case records. Public health. 2000; 114(2): 143-5. doi: 10.1038/sj.ph.1900623.

6) Montazeri A, Vahdaninia M, Harirchi I, Harirchi AM, Sajadian A, Khaleghi F, et al. Breast cancer in Iran: need for greater women awareness of warning signs and effective screening methods. Asia Pacific Family Medicine. 2008; 7(1): 1. doi: 10.1186/1447-056X-7-6, PMid: 19099595, PMCid: PMC2628874.

7) Harirchi I, Kolahdoozan S, Karbakhsh M, Chegini N, Mohseni S, Montazeri A, et al. Twenty years of breast cancer in Iran: downstaging without a formal screening program. Annals of oncology. 2011; 22(1): 93-7. doi: 10.1093/annonc/mdq303, PMid: 20534622.

8) Green BB, Taplin SH. Breast cancer screening controversies. The Journal of the American Board of Family Practice. 2003; 16(3): 233-41. doi: 10.3122/jabfm.16.3.233.

9) Feig SA, D'Orsi CJ, Hendrick RE, Jackson V, Kopans DB, Monsees B, et al. American College of Radiology guidelines for breast cancer screening. AJR American journal of roentgenology. 1998; 171(1): 29-33. doi: 10.2214/ajr.171.1.9648758, PMid: 9648758.

10) Force UPST. Screening for breast cancer: US Preventive Services Task Force recommendation statement. Annals of internal medicine. 2009; 151(10): 716. doi: 10.7326/0003-4819-151-10-200911170-00008, PMid: 19920272.

11) Elmore JG, Armstrong K, Lehman CD, Fletcher SW. Screening for breast cancer. Jama. 2005; 293(10): 1245-56. doi: 10.1001/jama.293.10.1245, PMid: 15755947, PMCid: PMC3149836.

12) Rauscher GH, Johnson TP, Cho YI, Walk JA. Accuracy of self-reported cancer-screening histories: a metaanalysis. Cancer Epidemiology Biomarkers \& Prevention. 2008; 17(4): 748-57. doi: 10.1158/10559965.EPI-07-2629, PMid: 18381468.

13) Jafarzadeh N, Ashraf H, Khoshroo F, Shamloo AS, Bidouei F, Ghaffarzadehgan K. Triple Negative Breast Cancer: Molecular Classification, Prognostic Markers and Targeted Therapies. Razavi International Journal of Medicine. 2015; 3(2): 1-7. doi: 10.5812/rijm.3(2)2015.24992. 
14) Aalipour E, Jangholi E. Prognosis and Predictive Factors Related to Breast Cancer. Galen Medical Journal. 2016; 5(2): 45-8.

15) Mirmalek SA, Elhamkani F, Tabatabaee SAS, Mahmoodzadeh H, Parsa Y, Yadollah-Damavandi S, et al. Introduction of HER-2 and a short review on its role in prognosis and treatment of breast cancer. Galen Medical Journal. 2014; 3(3): 132-44.

16) Radenkovic S, Konjevic G, Isakovic A, Stevanovic P, Gopcevic K, Jurisic V. HER2-positive breast cancer patients: correlation between mammographic and pathological findings. Radiation protection dosimetry. 2014: ncu243. doi: 10.1093/rpd/ncu243, PMid: 25063784.

17) Harirchi I, Karbakhsh M, Kashefi A, Momtahen AJ. Breast cancer in Iran: results of a multi-center study. Asian pacific journal of cancer prevention. 2004; 5(1): 24-7, PMid: 15075000.

18) Vahdaninia M, Montazeri A. Breast cancer in Iran: a survival analysis. Asian pacific journal of cancer prevention. 2004; 5(2): 223-5, PMid: 15244529.

19) Li C, Uribe D, Daling J. Clinical characteristics of different histologic types of breast cancer. British journal of cancer. 2005; 93(9): 1046-52. doi: 10.1038/sj.bjc.6602787, PMid: 16175185, PMCid: PMC2361680.

20) Jemal A, Siegel R, Ward E, Hao Y, Xu J, Murray T, et al. Cancer statistics, 2008. CA: a cancer journal for clinicians. 2008; 58(2): 71-96. doi: 10.3322/ca.2007.0010.

21) Moradi MM HF, Shamsian AA, Eftekharzade MI, Hedayati-Moghadam MR, Bidkhori HR, et al. [Relationship between oncogen HER-2, P53, estrogen and progesterone receptor status with survival Rate in Iranian women with breast cancer]. Iran J Breast Dis 2009; 1: 7-16.

22) Mofid B JNM, Kiani L, Zaeri F. [Evaluate the Relationship between oncogen HER-2 With Prognostic Factors in Breast Cancer, research in Medical Sciences]. Iran J Breast Dis 2009; 28: 29-32.

23) Sirati F GA, Alavi N. [Determine the prevalence of prognostic factors (ER, PR, P53, HER-2/neu) in Breast Cancer and investigate their relationship with each other and with the patient's age and menopausal status]. Iran J Breast Dis 2009; 1: 24-31.

24) Kadivar M RM, Jadidfard R. [Evaluation of histopathology and biologic markers in premenopausal (under 40 years) and postmenopausal (over 60 years) women with breast cancer in Hazrat-e-Rasoul and Atieh hospital]. Journal of Iran University of Medical Sciences. 2010; 17: 49-57.

25) Huang H-J, Neven P, Drijkoningen M, Paridaens R, Wildiers H, Van Limbergen E, et al. Association between HER-2/neu and the progesterone receptor in oestrogen-dependent breast cancer is age-related. Breast Cancer Research and Treatment. 2005; 91(1): 81-7. doi: 10.1007/s10549-004-8235-8, PMid: 15868434.

26) Bauer KR, Brown M, Cress RD, Parise CA, Caggiano V. Descriptive analysis of estrogen receptor (ER) negative, progesterone receptor (PR) - negative, and HER2 - negative invasive breast cancer, the so called triple - negative phenotype. Cancer. 2007; 109(9): 1721-8. doi: 10.1002/cncr.22618, PMid: 17387718.

27) Carey LA, Perou CM, Livasy CA, Dressler LG, Cowan D, Conway K, et al. Race, breast cancer subtypes, and survival in the Carolina Breast Cancer Study. Jama. 2006; 295(21): 2492-502. doi: 10.1001/jama.295.21.2492, PMid: 16757721.

28) Pisano ED, Gatsonis C, Hendrick E, Yaffe M, Baum JK, Acharyya S, et al. Diagnostic performance of digital versus film mammography for breast-cancer screening. New England Journal of Medicine. 2005; 353(17): 1773-83. doi: 10.1056/NEJMoa052911, PMid: 16169887.

29) Keyhanian sAJa, Lohrasbi Z, Fotoukian E, Saravi Z, Mansour M. Evaluation of Biologic Markers Frequency and Their Correlation with Some Determinant Prognostic Factors in Women with Breast Cancer Referred to Oncology Clinic of Imam Sajjad Hospital of Ramsar during 2002-2012. Journal of Ilam University of Medical Sciences. 2015; 22(7): 115-28.

30) Foulkes WD. Clinically relevant biology of hereditary breast cancer. Seminars in Oncology. 2007; 34(5): 379-83. doi: 10.1053/j.seminoncol.2007.07.010, PMid: 17920891. 